\title{
MATHEMATIKA
}

A JOURNAL OF PURE AND APPLIED MATHEMATICS

\author{
Edited by \\ H. DAVENPORT, W. R. DEAN, \\ J. G. SEMPLE
}

VOLUME 5

1958

Published by

THE DEPARTMENT OF MATHEMATICS

UNIVERSITY COLLEGE

LONDON 
Printed by

C. F. HODGSON \& SON, LTD.

23 PAKENHAM STREET

LONDON, W.C.1 


\section{INDEX TO VOLUME 5}

Page

BIRCH, B. J. and DAVENPORT, H. Indefinite quadratic forms in many variables 8

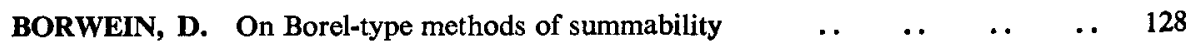

COHN, P. M. On a class of simple rings .. $\quad$.

COLLINS, W. D. Note on a sphere theorem for the axisymmetric flow of a viscous

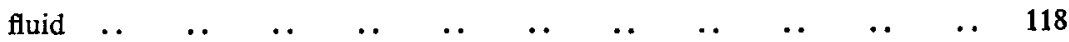

CROFT, H. T. Note on a plane measure problem $\quad \begin{array}{llllllll}\text {. } & \ldots & \ldots & \ldots & \ldots & 125\end{array}$

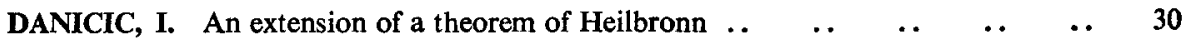

DAVENPORT, H. See BIRCH, B. J.

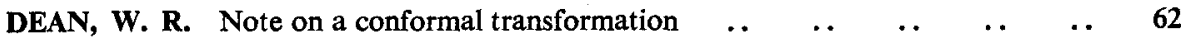

- An application in hydrodynamics of the Green's function of an elastic plate 85

EDWARDS, R. E. Derivatives of vector-values functions $\quad \ldots \quad$.

HASELGROVE, C. B. A disproof of a conjecture of Polya $\quad \ldots \quad$.

HEILBRONN, H. On the averages of some arithmetical functions of two variables 1

HOCKING, L. M. A doublet technique for solving Oseen's equations of axisymmetric $\quad 82$

$\begin{array}{llllllllllllll}\text { flow } & . & \ldots & . & \ldots & \ldots & \ldots & \ldots & \ldots & \ldots & \ldots & \ldots & \ldots & 134\end{array}$

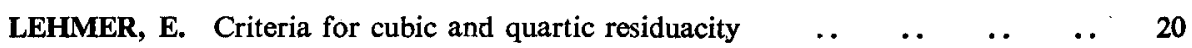

MACLANE, S. A proof of the subgroup theorem for free products .. $\quad \ldots \quad$.. 13

$\begin{array}{llllll}\text { MICHAEL, D. H. The separation of a viscous liquid at a straight edge } & \ldots & \ldots & 82\end{array}$

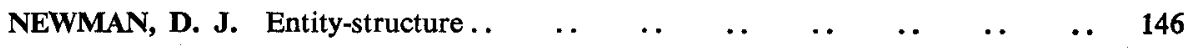

RIDOUT, D. The $p$-adic generalization of the Thue-Siegel-Roth theorem $\quad \ldots \quad \ldots \quad 40$

$\begin{array}{llllllllllll}\text { — Indefinite quadratic forms } & \ldots & \ldots & \ldots & \ldots & \ldots & \ldots & \ldots & \ldots & 122\end{array}$

ROGERS, C. A. and SHEPHARD, G. C. Some extremal problems for convex bodies 93

SHEPHARD, G. C. See Rogers, C. A.

TRUSTRUM, G. B. On sequences of integers $\quad \ldots \begin{array}{lllllllll} & \ldots & \ldots & \ldots & \ldots & \ldots & \ldots & & \end{array}$

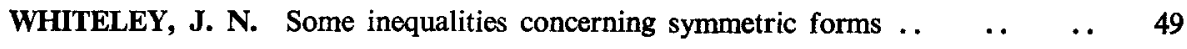

$\begin{array}{llllllll}\text { WIGGLESWORTH, L. A. Stress relief in a cracked plate } & \ldots & \ldots & \ldots & & \ldots & 67\end{array}$ 